\title{
Causal-Comparative Macroeconomic Behavioral Study: International Corporate Financial Transfer Pricing in the United States
}

\author{
http://doi.org/ 10.21272/fmir.4(1). 60-75.2020
}

Karina Kasztelnik, ORCID: http://orcid.org/0000-0002-1090-3700

Ph.D., MBA, CPA, CTP, Grand Canyon University, Phoenix, Arizona, USA

\begin{abstract}
This research paper summarizes the ideas of maximization of corporate welfare and basic firm theory, transfer prices among corporate subsidiaries have been found to complicate performance evaluations of subsidiaries and the parent company. The research problem addressed the lack of understanding of transfer price policy and its application to impact firm profits within three specific measures: investor return, earnings per share, and effective tax rate. The main purpose of this study was to ascertain an empirical relationship between transfer pricing policies and these financial performance measures within a study of two multinational firms. The research paper presents of an empirical result indicated statistically significant differences between the measures for each firm and allowed further comparative analysis based on other collected data. Overall, results indicated each measure of performance affected transfer pricing tax liabilities and transfer pricing may be a vehicle to improve company profitability. The results of this study may contribute to positive social change by bringing a focus to efficiency in transfer pricing, which could yield positive impacts on the economy through the reduction of international transaction costs stemming from minimization of tariffs, income tax liabilities at home and abroad, foreign exchange risk and conflicts with foreign governments' policies. Positive social change may also be affected by providing investors a new perspective on corporate financial data based on transfer price policies and corporate performance.
\end{abstract}

Keywords: Finance, Transfer Pricing, Macroeconomy, Corporate Performance, Effective Tax Rate, Earnings Per Share, Investor Return.

JEI Classifications: A10; C49; C40; C44; C58; F38; B27.

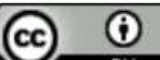

Cite as: Kasztelnik, K. (2020). Causal-Comparative Macroeconomic Behavioral Study: International Corporate Financial Transfer Pricing in the United States. Financial Markets, Institutions and Risks, 4(1), 6075. http://doi.org/ 10.21272/fmir.4(1). 60-75.2020

(C) The Author, 2020. This article is published with open access at Sumy State University.

\section{Introduction}

Multinational firms make international investments in order to improve their global competitive position in the international market. These firms may then be in a better position to take advantage of international differences in taxation, capital markets, and product costs. The company must have an attitude of globalization that makes it as concerned and involved with each of its foreign operations as with its U.S. operations to achieve the objective of enhanced global competitiveness. Although firms may enter the international market to improve their global competitiveness, entering the international market also brings the potential impact from various issues. Political and legal issues will affect the firm. Nguyen Tan (2009) discussed some of these issues more completely:

These issues represent instability, uncertainty and interference from the political and legal entities through price controls, government instability, changes of political groups or government regime change, with each adding a certain degree of risk often with significant effect on the transfer pricing performance evaluation. (Nguyen Tan, 2009, p. 225)

The U.S. tax authority of the branch will not object to the transfer price, since their tax revenue is increased by a high profit, but the tax administrators of the parent headquarter company will find the existing transfer price and lost tax revenue objectionable (Wong, Nassiripour, Mir \& Healy, 2011). The economic models developed by Washington Consensus economists are based upon between three and six basic risk assumptions that are meant to relate to the real global world. Therefore, this study proposed other risk measurement all 
transfer pricing issues in the company to maximize profit with an eye toward determining optimal national tax policy. Göx and Schiller (2007) provide an overview of how management accounting researchers hence started focusing on frictions such as information asymmetry to this research.

\section{Background and Hypotheses}

A central question in global economics is how the intercompany transactions policy affects real activity over the business cycle. This study describes two projects aimed at investigating both the importance of the transfer pricing practice and the implications of theoretical models of the transfer pricing for the conduct of transfer pricing policy (Adams, L. \& Drtina, R. (2008). The first part of the research is an ex post facto study that analyzes two companies' multinational business cycle characteristics of the basic financial information, such as corporate missions, strategies, financial goals, transfer pricing practices, income taxes, and tax planning strategies (Baldenius, T., Melumad, N. \& Reichelstein S., 2004). The first part of the research also contains analysis of other measures of the profit performance, such as investor return, earnings per share, current tax rate, and effective tax rate. The focus on the study is to set up better reconciliation of the intercompany transactions. The primary characteristics of multinational firms are constructed using the financial data from publicly available sources (Adams, C., \& Coombes, R.,2003).

The second part of the research builds a model consistent with the findings of the first part of the research. In the model, the relationship between profit performance and investor return, or earnings per share, affects the transfer pricing tax liabilities. The broader impacts are that the research will help improve the methods of global transfer pricing policy over the business cycle (Chan, K. \& Hung - Chow, L. 1997). The research could also help in the design of policy aimed at regulating the leading manufacturers of highly engineered products in the United States and abroad. The research described here will be disseminated broadly in academic journals as well as publications intended for the new global accounting regulatory policymakers (Alm, J., MartinezVazquez, J., \& Rider, M., 2006)

The following research questions guided this study:

Research Question 1: What is the relationship between profit performance and investors' return in the two multinational companies, Eaton and Whirlpool, in the electronics, electrical, and equipment industry in the U.S.?

Null Hypothesis 1: There is no relationship between profit performance and investors' return in the two multinational companies, Eaton and Whirlpool, in the electronics, electrical, and equipment industry.

Test Hypothesis 1: There is a statistically significant relationship between profit performance and investors' return in the two multinational companies, Eaton and Whirlpool, in the electronics, electrical, and equipment industry

Research Question 2: What is the relationship between profit performance and earnings per share in the two multinational companies, Eaton and Whirlpool, in the electronics, electrical, and equipment industry in the U.S.?

Null Hypothesis 2: There is no relationship between profit performance and earnings per share in the two multinational companies, Eaton and Whirlpool, in the electronics, electrical, and equipment industry.

Test Hypothesis 2: There is a statistically significant relationship between profit performance and earnings per share in the two multinational companies, Eaton and Whirlpool, in the electronics, electrical, and equipment industry.

Research Question 3: What is the relationship between current tax rates and effective tax rates in the two multinational companies, Eaton and Whirlpool, in the electronics, electrical, and equipment industry in the U.S.?

Null Hypothesis 3: There is no relationship between current tax rates and effective tax rates in the two multinational companies, Eaton and Whirlpool, in the electronics, electrical, and equipment industry.

Test Hypothesis 3: There is a statistically significant relationship between current tax rates and effective tax rates in the two multinational companies, Eaton and Whirlpool, in the electronics, electrical, and equipment industry. 


\section{Research Design}

This section will explain the statistical methodology adopted to analyze the research questions. For purposes of this study, the $t$ test statistical analysis is used as part of the research methodology. The overall research method is one of ex post facto design to collect financial data from two multinational companies for the two years prior to December 31, 2010. External financial data were collected on the official database financial statement from January 1, 2008 to December 31, 2009.

The first set of comparisons examined the profit performance and investor returns separate for both multinational companies. Three years of financial statement data were collected for both groups. The following accounting based measures served as independent variables for purposes of this study and were used as points of comparison: profit performance (i.e., profits net after taxes, after extraordinary credits, or charges if any appear on the income statement, and after cumulative effects of accounting changes) and investor returns (i.e., total return to investors, including price appreciation and dividend yield to an investor in the company's stock). By comparing the means of two independent samples on these measurements through a series of $t$ tests, it was possible to determine in which areas, if any, the first group was outperforming the second group for each separate business entities. By evaluating the group results on these measures as a whole, it will be possible to determine the overall impact of the transfer pricing policy to profit performance and investor return in multinational companies in the electronics, electrical, and equipment industry (Avi-Yonach, R.S., 2007).

The second set of comparisons examined the profit performance and earnings per share separate for both tested multinational companies. Three years of financial statement data were collected for both experimental groups. The following accounting-based measures served as independent variables for purposes of this study and will be used as points of comparison: profit performance and earnings per share (EPS is the diluted EPS appearing on the income statement of each company). By comparing the means of two independent simples on these measurements, through a series of $t$ tests, it was determined in which areas, if any, the first group had outperformed the second group for each separate business industry (Elliott, J. \& Emmanuel, C. 2000). Both entities were provided the same type of business industry; however, the global transfer pricing approach will be different. By evaluating the group results on these measures as a whole it was possible to determine the overall impact of the transfer pricing policy to profit performance, and earnings per share in multinational companies in the electronics, electrical, and equipment industry (Baker, J.C. \& McKenzie, G.W., 1993).

The third set of comparisons examined the profit performance, and earnings per share separate for both tested multinational companies. Three years of financial statement data was collected for both experimental groups. The following accounting-based measures serve as independent variables for purposes of this study and were used as points of comparison: Current tax rate (i.e., figure applied to the tax base), and effective tax rate (i.e., tax rates based on economic income rather than taxable income). By comparing the means of two independent samples on these measurements, through a series of $t$ tests, it was possible to determine in which areas, if any, the first group will be outperforming the second group for each separate business entities. By evaluating the group results on these measures as a whole it was possible to determine the overall impact of the transfer pricing policy to current tax rate and effective tax rate in multinational companies in the electronics, electrical, and equipment industry (Bergstrand, J., 2012).

\section{Instrumentation and Data Collection Procedures}

The two samples were independent of each other in the sense that they came separate samples containing different sets of individual subjects. The individual measures in Group A was in no way be linked with, or related to any of the individual measures in Group B, and vice versa. The version of a $t$ test examined in these sections assessed the significance of the difference between the means of two such samples, providing (a) that the two samples are randomly drawn from normally distributed populations and (b) that the measures of which the two samples will compose as the equal-interval. TI used a nondirectional research hypothesis due to the expectation of a difference in one direction $\left(\mathbf{M}_{\mathbf{a}}>\mathbf{M}_{\mathbf{b}}\right)$, or the other $\left(\mathbf{M}_{\mathbf{b}}>\mathbf{M}_{\mathbf{a}}\right)($ Boos, M., 2003).

\section{Data Analysis and Test of Assumptions}

A list of hypotheses related to the research questions are included below. All hypotheses were tested utilizing $t$ tests of significance on the means of the samples. 
Null Hypothesis 1: There is not be a significant difference between firms, at a 0.05 level of significance, in profit performance and investor's return

Test Hypothesis 1: There is be a positive significant difference firms, at a 0.05 level of significance, in profit performance and investor's return

The financial results for all business industry were collected for a period of 3 years prior to this study. The mean of each subgroup were calculated on the variables of investor return. Then, a $t$ test of significance with a confidence level of $95 \%$ will performed on all variables in order to test the null hypothesis.

Null Hypothesis 2: There is not be a significant difference between firms, at a 0.05 level of significance, in profit performance and earnings per share

Test Hypothesis 2: There is a positive significant difference firms, at a 0.05 level of significance, in profit performance and earnings per share

The financial results for all business industry where be collected for a period of 3 years prior to this study. The mean of each subgroup was calculated on the variables of earnings per share. Then, a $t$ test of significance with a confidence level of $95 \%$ will perform on all variables in order to test the null hypothesis.

Null Hypothesis 3: There is not a significant difference between firms, at a 0.05 level of significance, in the current tax rate and effective tax rate

Test Hypothesis 3: There is be a positive significant difference firms, at a 0.05 level of significance, in the current tax rate and effective tax rate

The financial results for all business industry were collected for a period of 3 years prior to this study. The mean of each subgroup was calculated on the variables of effective tax rate. Then, a $t$ test of significance with a confidence level of $95 \%$ will be performed on all variables in order to test the null hypothesis. The major assumption is that the company will achieve the outstanding performance and the corporate policy over which the subsidiary manager has the proper control. Poor performance may be attributed to environmental variability or corporate policy over which the subsidiary manager will have no control (Buckley, P..J, 2004).

\section{Results}

Whirlpool is the world's leading manufacturer and marketer of major home appliances makers. The company divides its corporate structure into four regionally based segments of North America, Europe, Latin America and Asia. It manufactures washers, dryers, refrigerators, air conditioners, dishwashers, freezers, microwave ovens, ranges, trash compactors, air purifiers, and more. In addition to Whirlpool, the company sells its products under a bevy of brand names, including KitchenAid, Maytag, Jenn-Air, Roper, Amana, and Magic Chef (Walden, 2003). As a global enterprise, Whirlpool has intrafirm trade of goods and services between operational segments. The company uses standard full cost-plus markup as the transfer price for finished goods. Full cost has been defined to include transfer cost from factory, warehousing, engineering, inland freight, and interest charge.

\section{Discussion}

These two corporations are a diverse group of products companies. Basic information about these two companies is summarized in Table 1. As shown in the table, both belonged in the Fortune 500 directory in 2009 and 2008. Whirlpool Corporation, the largest of both, had about $\$ 17$ billion in revenue in 2009. Eaton Corporation, the smallest of the group, had revenue of about $\$ 12$ billion in the same year. As shown in, these companies' assets and stockholders' equities also vary significantly (Case, K.E., Fair, R.C., and Oster, S.M., 2009). Despite the diversity of the products between these two corporations, they share some common characteristics; they are both multinational companies with subsidiaries in Canada, Europe, Asia, South America, and Australia, but are decentralized so that their strategic business units such as products or regional groups are autonomous units. The headquarters of these companies are located in the Midwestern states of Michigan (Whirlpool) and Ohio (Eaton).

Research Question 1 is a comparison of profit performance and investor's return conducted to addresses the impact of transfer pricing accounting treatment on investor's return. Net income percentage is used to determine the proportion of income derived from all operating, financing, and other activities that an entity has engaged in during an accounting period. This figure is the one most used as a benchmark for determining a company's performance. In this study, the author measures the impact of the principle transfer pricing in the company on the investor's return and the profit performance. Net income is the positive difference between 
income and expenses in the period under review and is thus the bottom line of the income statement. It shows a corporation's income for a period (Samuelson, L. 1982). When calculating this figure profits or losses carried forward and additions to, or withdrawals from open reserves are not considered. Net income is the initial figure for calculating other important ratios such as earnings per share, return on equity or return on sales (Cadwalader, W.T., 1992). Return on equity percentage is used by investors to determine the amount of return they are receiving from their capital investment in a company. The return on equity is calculated by dividing net income excluding extraordinary items by total equity (i.e., the common shareholder's equity). This indicator shows the rate of return on shareholder's capital for the period. Given constant profits, the return on equity increases the lower level of equity employed as leverage effect. A company's goal must be to generate a return that corresponds to the interest rate on the capital markets plus an industry-dependent risk premium in total generally between 5 and $10 \%$. Investor's return is a strong indicator for investments and highly relevant in practice. Table 1 through Table 8 . provide a comparison of profit performance and investor's return among Whirlpool and Eaton Companies for 2007, 2008, and 2009. Aggregate Total Comparison of Profit Performance and Investor's Return $t$ Test. Descriptive Statistics - Mann-Whitney 2 tailed Test Results for Whirlpool Inc.

Table 1. Mann-Whitney Test Results for: Whirlpool Inc. Profit Performance for the period $2007-2009$. Investor's Return for the period $2007-2009$

\begin{tabular}{|c|c|c|c|c|}
\hline \multicolumn{2}{|c|}{ Descriptive Statistics } & & & \\
\hline & Value & & Rank & Investor's Return \\
\hline & Profit Performance & Investor's Return & Profit Performance & 1.0 \\
\hline & & & & 4.0 \\
\hline 2009 year & 328.000 & 9.000 & 5.0 & 3.0 \\
\hline 2008 year & 418.000 & 13.900 & 5.0 & 2.0 \\
\hline Median & 640.000 & 16.500 & 3 & 3.0 \\
\hline Sum & 418.000 & 13.900 & 3.0 & 3 \\
\hline N & 1386.000 & 3 & & \\
\hline 2-tailed Test & 3 & & & \\
\hline U & & DF 2 & & \\
\hline 9.000 & 3 & 3 & & \\
\hline
\end{tabular}

Source: Compiled by Author.

Table 2. Linear Descriptive Statistics - Mann-Whitney 2 tailed Test Results for Whirlpool Inc.

\begin{tabular}{|c|c|c|}
\hline \multicolumn{2}{|c|}{ Profit Performance \& Investor's Return } \\
\hline \multicolumn{2}{|c|}{ Descriptive Statistics for: Whirlpool } \\
\hline & Profit Performance & Investor's Return \\
\hline Mean & 462.000 & 13.133 \\
\hline Median & 418.000 & 13.900 \\
\hline Std Error & 111.000 & 1.300 \\
\hline Std Dev. & 156.978 & 1.838 \\
\hline
\end{tabular}

Source: Compiled by Author.

Table 3. Linear Descriptive Statistics - Mann-Whitney 1 tailed Test Results for Whirlpool Inc.

\begin{tabular}{|c|c|c|c|c|}
\hline \multicolumn{5}{|c|}{ Mann-Whitney Test Results for: Whirlpool Inc } \\
\hline \multicolumn{5}{|c|}{ Profit Performance } \\
\hline \multicolumn{5}{|c|}{ Investor's Return } \\
\hline \multicolumn{5}{|c|}{ Descriptive Statistics } \\
\hline & Value & & Rank & \\
\hline & Profit Performance & Investor's Return & Profit Performance & Investor's Return \\
\hline 2009 year & 328.000 & 9.000 & 4.0 & 1.0 \\
\hline 2008 year & 418.000 & 13.900 & 5.0 & 2.0 \\
\hline 2007 year & 640.000 & 16.500 & 6.0 & 3.0 \\
\hline Median & 418.000 & 13.900 & 5.0 & 2.0 \\
\hline Sum & 1386.000 & 39.400 & 15.0 & 6.0 \\
\hline $\mathrm{N}$ & 3 & 3 & & \\
\hline \multicolumn{5}{|c|}{ 1-tailed Test (Profit Performance $>$ Investor's Return) } \\
\hline $\mathrm{U}$ & DF 1 & DF 2 & $\mathrm{P}$ & \\
\hline 9.000 & 3 & 3 & 0.049 & \\
\hline
\end{tabular}

Source: Compiled by Author.

Table 4. Linear Descriptive Statistics - Mann-Whitney 1 tailed Test Results for Whirlpool Inc. 


\begin{tabular}{|c|c|c|c|}
\hline \multicolumn{2}{|c|}{ Mann-Whitney Test Results for: } & Whirlpool & \\
\hline \multicolumn{2}{|c|}{ Profit Performance } & & \\
\hline \multicolumn{2}{|c|}{ Investor's Return } & & \\
\hline & & & \\
\hline \\
\hline
\end{tabular}

Table 5. Descriptive Statistics - Mann-Whitney Tailed Test Results for Eaton Corp.

\begin{tabular}{|c|c|c|c|c|}
\hline \multicolumn{5}{|c|}{ Mann-Whitney Test Results for: Eaton Corp. } \\
\hline \multicolumn{5}{|c|}{\begin{tabular}{|l|l} 
Profit Performance & \\
\end{tabular}} \\
\hline \multicolumn{5}{|c|}{ Investor's Return } \\
\hline \multicolumn{5}{|c|}{ Descriptive Statistics } \\
\hline & Value & & Rank & \\
\hline & Profit Performance & Investor's Return & Profit Performance & Investor's Return \\
\hline 2009 year & 383.000 & 5.700 & 4.0 & 1.0 \\
\hline 2008 year & 1058.000 & 16.700 & 6.0 & 2.0 \\
\hline 2007 year & 994.000 & 18.500 & 5.0 & 2.0 \\
\hline Median & 994.000 & 16.700 & 5.0 & 2.0 \\
\hline Sum & 2435.000 & 40.900 & 15.0 & 6.0 \\
\hline $\mathrm{N}$ & 3 & 3 & 3 & 3 \\
\hline \multicolumn{5}{|l|}{ 2-tailed Test } \\
\hline $\mathrm{U}$ & DF 1 & DF 2 & $\mathrm{P}$ & \\
\hline 9.000 & 3 & 3 & 0.100 & \\
\hline
\end{tabular}

Source: Compiled by Author.

Table 6. Linear Descriptive Statistics - Mann-Whitney 2 tailed Test Results for Eaton Corp.

\begin{tabular}{|l|c|l|}
\hline \multicolumn{2}{|c|}{ Descriptive Statistics for: } & \multicolumn{2}{|c|}{ Profit Performance \& Investor's Return } \\
\hline \multicolumn{2}{|c|}{} & \multicolumn{1}{|c|}{} \\
\hline & Profit Performance & Investor's Return \\
\hline Mean & 811.667 & 13.633 \\
\hline Median & 994.000 & 16.700 \\
\hline Std Error & 32.000 & 0.900 \\
\hline Std Dev. & 45.255 & 1.273 \\
\hline
\end{tabular}

Table 7. Linear Descriptive Statistics - Mann-Whitney 1 tailed Test Results for Eaton Corp.

\begin{tabular}{|c|c|c|c|c|}
\hline \multicolumn{5}{|c|}{ Mann-Whitney Test Results for: Eaton } \\
\hline \multicolumn{5}{|c|}{ Profit Performance } \\
\hline \multicolumn{5}{|c|}{ Investor's Return } \\
\hline \multicolumn{5}{|c|}{ Descriptive Statistics } \\
\hline & Value & & Rank & \\
\hline & Profit Performance & Investor's Return & Profit Performance & Investor's Return \\
\hline 2009 year & 383.000 & 5.700 & 4.0 & 1.0 \\
\hline 2008 year & 1058.000 & 16.700 & 6.0 & 2.0 \\
\hline 2007 year & 994.000 & 18.500 & 5.0 & 3. \\
\hline Median & 994.000 & 16.700 & 5.0 & 2.0 \\
\hline Sum & 2435.000 & 40.900 & 15.0 & 6.0 \\
\hline $\mathrm{N}$ & 3 & 3 & 3 & 3 \\
\hline \multicolumn{4}{|c|}{ 1-tailed Test (Profit Performance $>$ Investor's Return) } & \\
\hline $\mathrm{U}$ & DF 1 & DF 2 & $\mathrm{P}$ & \\
\hline 9.000 & 3 & 3 & 0.049 & \\
\hline
\end{tabular}

Source: Compiled by Author. 
Table 8. Linear Descriptive Statistics - Mann-Whitney 1 tailed Test Results for Eaton Corp.

\begin{tabular}{|c|c|c|c|c|}
\hline \multicolumn{4}{|c|}{ Mann-Whitney Test Results for: Eaton } & \\
\hline \multicolumn{5}{|c|}{ Profit Performance } \\
\hline \multicolumn{5}{|c|}{ Investor's Return } \\
\hline \multicolumn{5}{|c|}{ Descriptive Statistics } \\
\hline & Value & & Rank & \\
\hline 2009 year & 383.000 & 5.700 & 4.0 & 1.0 \\
\hline 2008 year & 1058.000 & 16.700 & 6.0 & 2.0 \\
\hline 2007 year & 994.000 & 18.500 & 5.0 & 3.0 \\
\hline Median & 994.000 & 16.700 & 5.0 & 2.0 \\
\hline Sum & 2435.000 & 40.900 & 15.0 & 6.0 \\
\hline $\mathrm{N}$ & 3 & 3 & 3 & 3 \\
\hline \multicolumn{4}{|c|}{ 1-tailed Test (Profit Performance $<$ Investor's Return) } & \\
\hline $\mathrm{U}$ & DF 1 & DF 2 & $\mathrm{P}$ & \\
\hline 0.000 & 3 & 3 & 1.000 & \\
\hline
\end{tabular}

Source: Compiled by Author.

The data collected was analyzed using statistical tools. The $t$ test was conducted with using the Mann-Whitney statistics to test the null hypothesis that two independent samples come from the same population (distribution free). Their advantage over the independent-samples $t$-test is that Mann-Whitney and Wilcoxon do not assume normality and can be used to test ordinal variables. A non-parametric test "The Mann-Whitney and Wilcoxon" is distribution free used to compare two independent groups of sampled data.

Alternative hypothesis:

$\mathrm{X} \neq \mathrm{Y}$ to test if the median $(\mathrm{X})$ is not equal to median $(\mathrm{Y})$

$\mathrm{X}>\mathrm{Y}$ to test if the median $(\mathrm{X})$ is greater than median $(\mathrm{Y})$

$\mathrm{X}<\mathrm{Y}$ to test if the median $(\mathrm{X})$ is less than median $(\mathrm{Y})$

F-Test for the Significance of the Difference between the Variances of the Two Independent Samples. P $>.05$ indicates no significant difference detected between the variances of the two samples. The test result of the one-tailed $U$ test are given, including the $U$ value (9.000), degree of freedom (DF1 $=3$, and DF2 $=3$ ) and the probability value $(\mathrm{P})$, which in this example is $<0.05$ and indicates that we accept the hypothesis that the median for Set 1 (Profit Performance) is greater than the median for Set 2 (Investor's Return). If the null hypothesis had been that the median for Set 1 (Profit Performance) was less than the median for Set 2 (Investor's Return), then the one-tailed $U$ test would have had a $U$ value of 0.0 (degrees of freedom of 3 and 3 ) with probability $(\mathrm{P})$ of 1.000 , and we would reject the null hypothesis that Set 1 (Profit Performance) decreased compare to the Set 2 (Investor's Return). F-Test for the Significance of the Difference between the Variances of the Two Independent Samples. P > .05 indicates no significant difference detected between the variances of the two samples. The $t$ test assuming unequal sample variances and applicable only to independent samples. The study revealed a t-test value by dividing the Mean difference $(811.667-13.633=$ 798.033 ) by the standard error (31.100) which is equal to 25.660 for 2-tailed test. The test result of the onetailed $U$ test are given, including the $U$ value $(9.000)$, degree of freedom $(D F 1=3$, and DF2 $=3$ ) and the probability value $(\mathrm{P})$, which in this example is $<0.05$ and indicates that we accept the hypothesis that the median for Set 1 (Profit Performance) is greater than the median for Set 2 (Investor's Return). If the null hypothesis had been that the median for Set 1(Profit Performance) was less than the median for Set 2 (Investor's Return), then the one-tailed U test would have had a U value of 0.0 (degrees of freedom of 3 and 3 ) with probability $(\mathrm{P})$ of 1.000 , and we would reject the null hypothesis that Set 1 (Profit Performance) decreased compare to the Set 2 (Investor's Return). In this study, the $t$ test is performed to test whether there are any significant differences on Profit Performance (PP) and Investor's Return (IR) ratios between the firms with foreign ownership participation in capital structure and domestic subsidiaries. The empirical findings obtained from t-test are summarized as follow: Whirlpool data yielded a T statistic of 4.09 and $\mathrm{P}$ value of 0.1 while Eaton returned a T statistic of 25.66 and a $\mathrm{P}$ value of 0.049 . The hypotheses to test effect of Profit Performance on Investor's Return are:

$\mathrm{H}_{0}$ : There is no significant difference between Profit Performance (PP) and Investor's Return (IR),

$\mathrm{H}_{1}$ : There is significant difference between Profit Performance (PP) and Investor's Return (IR). As it can be seen in the Model- $1 t$ test, for year 2007-2009, $\mathrm{H}_{0}$ is rejected $(\mathrm{p}=0.100<0.05)$. When PPs \& IRs are compared, it is found that the company Eaton Inc. is significantly different after $t$ test was performed $\left(\mathrm{t}_{0} .{ }_{0} ;{ }_{3}=25.66\right)$. 
According to the finding, IR of Eaton is higher than IRs of Whirlpool, which is $0.50 \%$. In the study, an analysis of performance of profit performance and investor's return conducted to addresses the impact of transfer pricing accounting treatment on investor's return was undertaken. Whether there is any significant performance difference between the PP and IR for both listed companies were reviewed. In the paper, $t$-test statistics confirms the hypothesis that Eaton Corp. in respect to IRs have performed better than Whirlpool Inc. Therefore, the results show that Eaton Corp. with foreign ownership performs better than Whirlpool Inc. with foreign ownership for the period 2007-2009.

\section{Comparison of Profit Performance and Earnings Per Share}

Research Question 2 is a comparison of profit performance and earnings per share to address the impact of transfer pricing accounting treatment on earnings per share. It is useful for shareholders to determine changes in earnings per share held over a period. When calculating earnings per share, the company's profits (net income), adjusted for extraordinary items, are divided by the average number of total common shares outstanding. The impact of the principle transfer pricing in the company on the earnings per year and the profit performance is measured. This indicator is used most often to describe a company's performance over time and is one of the basic of company valuation. EPS is used in company valuations and to many analyst estimates are freely accessible. Tables from 9 through 16 provide a comparison of profit performance and earnings per share among Whirlpool and Eaton Companies for 2007, 2008, and 2009.

\section{Aggregate Total Comparison of Profit Performance and Earnings Per Share $t$ Test}

Table 9. Descriptive Statistics - Mann-Whitney Tailed Test Results for Whirlpool Inc.

\begin{tabular}{|c|c|c|c|c|}
\hline Mann-Whitney Test Results for: & & Whirlpool Inc & & \\
\hline \multicolumn{5}{|l|}{ Profit Performance } \\
\hline \multicolumn{5}{|l|}{ Earnings Per Share } \\
\hline \multicolumn{5}{|l|}{ Descriptive Statistics } \\
\hline & Value & & Rank & \\
\hline & Profit Performance & Earnings Per Share & Profit Performance & Earnings Per Share \\
\hline 2009 year & 328.000 & 4.400 & 4.0 & 1.0 \\
\hline 2008 year & 418.000 & 5.570 & 5.0 & 2.0 \\
\hline 2007 year & 640.000 & 8.150 & 6.0 & 3.0 \\
\hline Median & 418.000 & 5.570 & 5.0 & 2.0 \\
\hline Sum & 1386.000 & 18.120 & 15.0 & 6.0 \\
\hline $\mathrm{N}$ & 3 & 3 & 3 & 3 \\
\hline \multicolumn{5}{|l|}{ 2-tailed Test } \\
\hline $\mathrm{U}$ & DF 1 & DF 2 & $P$ & \\
\hline 9.000 & 3 & 3 & 0.100 & \\
\hline
\end{tabular}

Source: Compiled by Author.

Table 10. Linear Descriptive Statistics - Mann-Whitney 2 tailed Test Results for Whirlpool Inc.

\begin{tabular}{|l|c|c|}
\hline Descriptive Statistics for: & \multicolumn{2}{|l|}{} \\
\hline Profit Performance \& Earnings Per Share & Earnings Per Share \\
\hline Mean & Profit Performance & 6.040 \\
\hline Median & 462.000 & 5.570 \\
\hline Std Error & 418.000 & 1.290 \\
\hline Std Dev. & 111.000 & 1.824 \\
\hline
\end{tabular}

Source: Compiled by Author.

Table 11. Linear Descriptive Statistics - Mann-Whitney 1 tailed Test Results for Whirlpool Inc.

\begin{tabular}{|c|c|c|c|c|}
\hline \multicolumn{2}{|c|}{ Mann-Whitney Test Results for: } & Whirlpool & & \\
\hline \multicolumn{5}{|c|}{ Profit Performance } \\
\hline \multicolumn{5}{|c|}{ Earnings Per Share } \\
\hline \multicolumn{5}{|c|}{ Descriptive Statistics } \\
\hline & Value & & Rank & \\
\hline & Profit Performance & Earnings Per Share & Profit Performance & Earnings Per Share \\
\hline 2009 year & 328.000 & 4.400 & 4.0 & 1.0 \\
\hline 2008 year & 418.000 & 5.570 & 5.0 & 2.0 \\
\hline Median & 418.000 & 5.570 & 5.0 & 2.0 \\
\hline Sum & 1386.000 & 18.120 & 15.0 & 6.0 \\
\hline $\mathrm{N}$ & 3 & 3 & 3 & 3 \\
\hline \multicolumn{4}{|c|}{ 1-tailed Test (Profit Performance $>$ Earnings Per Share) } & \\
\hline $\mathrm{U}$ & DF 1 & DF 2 & $\mathrm{P}$ & \\
\hline 9.000 & 3 & 3 & 0.049 & \\
\hline
\end{tabular}

Source: Compiled by Author. 
Table 12. Linear Descriptive Statistics - Mann-Whitney 1 tailed Test Results for Whirlpool Inc.

\begin{tabular}{|c|c|c|c|c|}
\hline \multicolumn{2}{|c|}{ Mann-Whitney Test Results for: } & Whirlpool & & \\
\hline \multicolumn{5}{|c|}{ Profit Performance } \\
\hline \multicolumn{5}{|c|}{ Earnings Per Share } \\
\hline \multicolumn{5}{|c|}{ Descriptive Statistics } \\
\hline & Value & & Rank & \\
\hline & Profit Performance & Earnings Per Share & Profit Performance & Earnings Per Share \\
\hline 2009 year & 328.000 & 4.400 & 4.0 & 1.0 \\
\hline 2008 year & 418.000 & 5.570 & 5.0 & 2.0 \\
\hline 2007 year & 640.000 & 8.150 & 6.0 & 3.0 \\
\hline Median & 418.000 & 5.570 & 5.0 & 2.0 \\
\hline Sum & 1386.000 & 18.120 & 15.0 & 6.0 \\
\hline $\mathrm{N}$ & 3 & 3 & 3 & 3 \\
\hline \multicolumn{5}{|c|}{ 1-tailed Test (Profit Performance $<$ Earnings Per Share) } \\
\hline $\mathrm{U}$ & DF 1 & DF 2 & $\mathrm{P}$ & \\
\hline 0.000 & 3 & 3 & 1.000 & \\
\hline
\end{tabular}

Source: Compiled by Author.

Table 13. Descriptive Statistics - Mann-Whitney Tailed Test Results for Eaton Corp.

\begin{tabular}{|c|c|c|c|c|}
\hline \multicolumn{2}{|c|}{ Mann-Whitney Test Results for: } & Eaton Corp. & & \\
\hline \multicolumn{5}{|c|}{ Profit Performance } \\
\hline \multicolumn{5}{|c|}{ Earnings Per Share } \\
\hline \multicolumn{5}{|c|}{ Descriptive Statistics } \\
\hline & Value & & Rank & \\
\hline & Profit Performance & Earnings Per Share & Profit Performance & Earnings Per Share \\
\hline 2009 year & 383.000 & 2.300 & 4.0 & 1.0 \\
\hline 2008 year & 1058.000 & 6.520 & 6.0 & 2.0 \\
\hline 2007 year & 994.000 & 6.610 & 5.0 & 3.0 \\
\hline Median & 994.000 & 6.520 & 5.0 & 2.0 \\
\hline Sum & 2435.000 & 15.430 & 15.0 & 6.0 \\
\hline $\mathrm{N}$ & 3 & 3 & 3 & 3 \\
\hline \multicolumn{5}{|c|}{ 2-tailed Test } \\
\hline $\mathrm{U}$ & DF 1 & DF 2 & $\mathrm{P}$ & \\
\hline 9.000 & 3 & 3 & 0.100 & \\
\hline
\end{tabular}

Source: Compiled by Author.

Table 14. Linear Descriptive Statistics - Mann-Whitney 2 tailed Test Results for Eaton Corp.

\begin{tabular}{|l|c|c|}
\hline Descriptive Statistics for: & Eaton Corp. \\
\hline Profit Performance \& Earnings Per Share & Earnings Per Share \\
\hline Mean & Profit Performance & 5.143 \\
\hline Median & 811.667 & 6.520 \\
\hline Std Error & 994.000 & 0.045 \\
\hline Std Dev. & 32.000 & 0.064 \\
\hline
\end{tabular}

Source: Compiled by Author.

Table 15. Linear Descriptive Statistics - Mann-Whitney 1 tailed Test Results for Eaton Corp.

\begin{tabular}{|c|c|c|c|c|}
\hline \multicolumn{2}{|c|}{ Mann-Whitney Test Results for: } & Eaton Corp. & & \\
\hline \multicolumn{5}{|c|}{ Profit Performance } \\
\hline \multicolumn{5}{|c|}{ Earnings Per Share } \\
\hline \multicolumn{5}{|c|}{ Descriptive Statistics } \\
\hline & Value & & Rank & \\
\hline & Profit Performance & Earnings Per Share & Profit Performance & Earnings Per Share \\
\hline 2009 year & 383.000 & 2.300 & 4.0 & 1.0 \\
\hline 2008 year & 1058.000 & 6.520 & 6.0 & 2.0 \\
\hline 2007 year & 994.000 & 6.610 & 5.0 & 3.0 \\
\hline Median & 994.000 & 6.520 & 5.0 & 2.0 \\
\hline Sum & 2435.000 & 15.430 & 15.0 & 6.0 \\
\hline $\mathrm{N}$ & 3 & 3 & 3 & 3 \\
\hline \multicolumn{5}{|c|}{ 1-tailed Test (Profit Performance $>$ Earnings Per Share) } \\
\hline $\begin{array}{l}\mathrm{U} \\
\end{array}$ & DF 1 & DF 2 & $\mathrm{P}$ & \\
\hline 9.000 & 3 & 3 & 0.049 & \\
\hline
\end{tabular}

Source: Compiled by Author. 
Table 16. Linear Descriptive Statistics - Mann-Whitney 1 tailed Test Results for Eaton Corp.

\begin{tabular}{|c|c|c|c|c|c|}
\hline Mann-Whi & st Results for: & & Eaton Corp. & & \\
\hline Profit Perfo & & & & & \\
\hline Earnings $\mathrm{P}$ & & & & & \\
\hline Descriptive & & & & & \\
\hline & Value & & Rank & & \\
\hline & Profit Performance & Earnings Per Share & Profit Performance & Earning & \\
\hline 2009 year & & & 2.300 & 4.0 & 1.0 \\
\hline 2008 year & & & 6.520 & 6.0 & 2.0 \\
\hline 2007 year & & & 6.610 & 5.0 & 3.0 \\
\hline Median & & & 6.520 & 5.0 & 2.0 \\
\hline Sum & & & 15.430 & 15.0 & 6.0 \\
\hline $\mathrm{N}$ & & & 3 & 3 & 3 \\
\hline & 1-tailed $\mathrm{Te}$ & t Performance $<$ Earn & & & \\
\hline $\mathrm{U}$ & & & DF 2 & $\mathrm{P}$ & \\
\hline 0.000 & & & 3 & 1.000 & \\
\hline
\end{tabular}

Source: Compiled by Author.

The $t$ test is conducted with using the Mann-Whitney statistics to test the null hypothesis that two independent samples come from the same population (distribution free). The advantage over the independent-samples $t$ test is that Mann-Whitney and Wilcoxon do not assume normality and can be used to test ordinal variables. A non-parametric test 'the Mann-Whitney and Wilcoxon' is distribution free used to compare two independent groups of sampled data.

Alternative hypothesis:

$\mathrm{X} \neq \mathrm{Y}$ to test if the median $(\mathrm{X})$ is not equal to median $(\mathrm{Y})$

$\mathrm{X}>\mathrm{Y}$ to test if the median $(\mathrm{X})$ is greater than median $(\mathrm{Y})$

$\mathrm{X}<\mathrm{Y}$ to test if the median $(\mathrm{X})$ is less than median $(\mathrm{Y})$

F-Test for the Significance of the Difference between the Variances of the Two Independent Samples. P > .05 indicates no significant difference detected between the variances of the two samples. The $t$ test assuming unequal sample variances and applicable only to independent samples. I obtained $t$-test values by dividing the Mean difference $(462.00-6.040=455.960)$ by the standard error $(109.710)$ which is equal to 4.156 for 2-tailed test. The test result of the one-tailed $U$ test are given, including the $U$ value (9.000), degree of freedom (DF1 $=3$, and DF2 $=3$ ) and the probability value $(\mathrm{P})$, which in this example is $<0.05$ and indicates that we accept the hypothesis that the median for Set 1 (Profit Performance) is greater than the median for Set 2 (Earnings Per Share).

If the null hypothesis had been that the median for Set 1(Profit Performance) was less than the median for Set 2 (Earnings Per Share), then the one-tailed $U$ test would have had a $U$ value of 0.0 (degrees of freedom of 3 and 3) with probability (P) of 1.000, and we would reject the null hypothesis that Set 1 (Profit Performance) decreased compare to the Set 2 (Earnings Per Share).

F-Test for the Significance of the Difference between the Variances of the Two Independent Samples. P $>.05$ indicates no significant difference detected between the variances of the two samples $t$ test assuming unequal sample variances and applicable only to independent samples. The output obtained a $t$ value by dividing the Mean difference $(811.667-5.143=806.523)$ by the standard error $(31.955)$ which is equal to 25.240 for 2 tailed test. The test result of the one-tailed $U$ test are given, including the $U$ value (9.000), degree of freedom $(\mathrm{DF} 1=3$, and $\mathrm{DF} 2=3)$ and the probability value $(\mathrm{P})$, which in this example is $<0.05$ and indicates that we accept the hypothesis that the median for Set 1 (Profit Performance) is greater than the median for Set 2 (Earnings Per Share). If the null hypothesis had been that the median for Set 1 (Profit Performance) was less than the median for Set 2 (Earnings Per Share), then the one-tailed U test would have had a U value of 0.0 (degrees of freedom of 3 and 3 ) with probability (P) of 1.000, and we would reject the null hypothesis that Set 1 (Profit Performance) decreased compare to the Set 2 (Earnings Per Share). In this study, the $t$ test is performed to test whether there are any significant differences on Profit Performance (PP) and Earnings per Share (EPS) ratios between the firms with foreign ownership participation in capital structure and domestic subsidiaries.

The empirical findings obtained from the $t$ test are summarized as follow: Whirlpool data yielded a T statistic of 4.169 and $\mathrm{P}$ value of 0.1 while Eaton returned a T statistic of 25.24 and a $\mathrm{P}$ value of 0.049 . 
The hypotheses to test the effect of Profit Performance on Earnings Per Share are:

$\mathrm{H}_{0}$ : There is no significant difference between Profit Performance (PP) and

Earnings Per Share (EPS),

$\mathrm{H}_{1}$ : There is significant difference between Profit Performance (PP) and

Earnings Per Share (EPS).

Model-2 T-test shows the result that, for year 2007-2009, $\mathrm{H}_{0}$ is rejected $(\mathrm{p}=0.100<0.05)$. When PPs \& EPSs are compared, it is found that the company Eaton Inc. is different significantly after the $t$-test was performed $\left(t_{0} .{ }_{0} ; ;_{3}=25.24\right)$. According to the finding, EPS of Eaton is lower than EPSs of Whirlpool, which is $0.9 \%$. In the study, an analysis of performance of profit performance and earnings per share conducted to addresses the impact of transfer pricing accounting treatment on earnings per share was undertaken. Whether there is any significant performance difference between the PP and EPS for both listed companies were reviewed. In the study, the $t$-test statistics confirms the hypothesis that Whirlpool Inc. in respect to EPSs have performed better than Eaton Corp. Therefore, the results show that Whirlpool Inc. with foreign ownership performs better than Eaton Corp. with foreign ownership for the period 2007-2009. Also, the study found that the adjustments to the transfer pricing were incorporated incorrectly in the Eaton Corp. The United States tax court had the evidence that Eaton Corporation and Subsidiaries didn't make the necessary adjustments pursuant to I. R. C. se. 482 under Docket No. 5576-12 in 2017.

Economic Partners (2017) wrote:

"In December 2011, the IRS notified Eaton that it was cancelling the first APA effective January 1, 2005, and the second APA effective January 1, 2006. The IRS contended that Eaton had material deficiencies in APA compliance including noncompliance with the terms of the APAs, errors in the supporting data and computations used in the transfer pricing methodologies ("TPMs") specified in the APAs, a lack of consistency in the application of the TPMs, the use of distortive accounting, and material facts that were misrepresented, mistakenly presented, or not presented in Eaton's submissions to the APA office. With the APA cancellation, the IRS determined deficiencies in Eaton's Federal income tax for 2005 and 2006 of USD 19.7 million and USD 55.3 million along with accuracy-related penalties of USD 14.3 million and USD 37.3 million." It confirms that this study was able to predict this situation between 2007 through 2009 by the appropriate financial analysis as presented in this research study.

\section{Comparison of Current Tax Rate and Effective Tax Rate}

Research Question 3 is a comparison of current tax rate and effective tax rate conducted to addresses the impact of transfer pricing accounting treatment on effective tax rate. For example, the federal income tax on individuals is imposed on taxable income. The tax base times the tax rates have produced the tax liability. Effective tax rate is tax rates based on economic income rather than taxable income. The tax effectively connected taxable income is used specifically to describe taxable income earned in the United States that is attributable to a foreign partner within multinational companies. The tax rate describes the relationship between income taxes and income before taxes, in order to show the relative impact on earnings from taxation. In the global economy, the tax rate is often a key criterion when companies chose where to locate. It is a reasonable indicator for a company's future tax rates in relatively stable tax systems. Table 17 provides a comparison of the current tax rate and the effective tax rate among Whirlpool and Eaton Companies for 2007, 2008, and 2009. The consequences of charging a higher transfer price are (a) a decrease in total tax liabilities and (b) an increase in the consolidated net income by the same amount.

Table 17. Eaton Corporation Effective Income Tax Rates

\begin{tabular}{|c|c|c|c|}
\hline & 2009 & 2008 & 2007 \\
\hline Income taxes at the United States Federal statutory rate & 35.0 & 35.0 & 35.0 \\
\hline \multicolumn{4}{|l|}{ United States operations } \\
\hline State \& local income taxes & 0.4 & 0.3 & 0.2 \\
\hline Deductible dividends & $(2.1)$ & $(0.5)$ & $(0.4)$ \\
\hline Deductible interest & $(2.3)$ & $(0.6)$ & $(0.6)$ \\
\hline Credit for increasing research activities & $(3.9)$ & $(1.2)$ & $(1.2)$ \\
\hline Other United States-net & 5.0 & 4.8 & 0.4 \\
\hline
\end{tabular}


Table 17 (cont.). Eaton Corporation Effective Income Tax Rates

\begin{tabular}{|c|c|c|c|}
\hline \multicolumn{4}{|l|}{ Non-United States operations } \\
\hline Foreign tax credit & $(2.5)$ & $(3.0)$ & $(1.2)$ \\
\hline Non-United States operations (earnings taxed at other than United States tax rate) & $(52.6)$ & $(18.9)$ & $(19.0)$ \\
\hline \multicolumn{4}{|l|}{ Worldwide operations } \\
\hline Adjustments to tax liabilities & $(11.9)$ & $(3.6)$ & $(5.6)$ \\
\hline Adjustments to valuation allowances & 7.7 & $(5.9)$ & 0.2 \\
\hline Effective income tax (benefit) expense rate & $(27.2)$ & 6.4 & 7.8 \\
\hline
\end{tabular}

Source: 2009 Eaton Annual Report.

Research question 3 is a comparative investigation conducted to addresses the impact of accounting treatment on tax transfer pricing. General speaking, the current tax rate should be higher than the effective tax rate. The overall benefit of the low effective tax rate is achieved at the lowest of the current tax liabilities. As a result, the collected data possess a fundamental estimation error. Since the errors in estimation reduce the beneficial role of effective tax, it should be more volatile than real taxes. To examine this relationship, the current tax rate and the effective tax rate are calculated for both companies an aggregate testing approach for periods 2007 to 2009. The annual financial reports of the firms are referenced to calculate the effective tax rate for both firms in the sample for years 2007 through 2009. The $t$ test is conducted with using the Mann-Whitney statistics to test the null hypothesis that two independent samples come from the same population (distribution free). Their advantage over the independent-samples $t$ test is that Mann-Whitney and Wilcoxon do not assume normality and can be used to test ordinal variables. A non-parametric test 'The Mann-Whitney and Wilcoxon' is distribution free used to compare two independent groups of sampled data.

Alternative hypothesis:

$\mathrm{X} \neq \mathrm{Y}$ to test if the median $(\mathrm{X})$ is not equal to median $(\mathrm{Y})$

$\mathrm{X}>\mathrm{Y}$ to test if the median $(\mathrm{X})$ is greater than median $(\mathrm{Y})$

$\mathrm{X}<\mathrm{Y}$ to test if the median $(\mathrm{X})$ is less than median $(\mathrm{Y})$

F-Test for the Significance of the Difference between the Variances of the Two Independent Samples. P > .05 indicates no significant difference detected between the variances of the two samples $t$ test assuming unequal sample variances and applicable only to independent samples. The output obtained a $t$ value by dividing the Mean difference $(35.000-38.933=-3.933)$ by the standard error $(-33.600)$ which is equal to 0.117 for $2-$ tailed test. The test result of the one-tailed $U$ test are given, including the $U$ value (6.000), degree of freedom $(\mathrm{DF} 1=3$, and DF2 $=3$ ) and the probability value $(\mathrm{P})$, which in this example is $>0.05$ and indicates that we can't accept the hypothesis that the median for Set 1 (Current Tax Rate) is greater than the median for Set 2(Effective Tax Rate) and we have to reject the test because median current tax rate is less than effective tax rate. Aggregate Total Comparison of Current Tax Rate and Effective Tax $t$ Test

Table 18. Descriptive Statistics - Mann-Whitney Tailed Test Results for Whirlpool Inc.

\begin{tabular}{|c|c|c|c|c|}
\hline \multicolumn{2}{|c|}{ Mann-Whitney Test Results for: } & Whirlpool Inc & & \\
\hline \multicolumn{5}{|c|}{ Current Tax Rate } \\
\hline \multicolumn{5}{|c|}{ Effective Tax Rate } \\
\hline \multicolumn{5}{|c|}{ Descriptive Statistics } \\
\hline & Value & & Rank & \\
\hline & Current Tax Rate & Effective Tax Rate & Current Tax Rate & Effective Tax Rate \\
\hline 2009 year & 35.000 & 20.600 & 4.0 & 2.0 \\
\hline 2008 year & 35.000 & 81.700 & 4.0 & 6.0 \\
\hline 2007 year & 35.000 & 14.500 & 4.0 & 1.0 \\
\hline Median & 35.000 & 20.600 & 4.0 & 2.0 \\
\hline Sum & 105.000 & 116.800 & 12.0 & 9.0 \\
\hline $\mathrm{N}$ & 3 & 3 & 3 & 3 \\
\hline \multicolumn{5}{|c|}{ 2-tailed Test } \\
\hline $\mathrm{U}$ & DF 1 & DF 2 & $\mathrm{P}$ & \\
\hline 6.000 & 3 & 3 & 0.700 & \\
\hline
\end{tabular}

Source: Compiled by Author.

Table 19. Linear Descriptive Statistics - Mann-Whitney 2 tailed Test Results for Whirlpool Inc.

\begin{tabular}{|l|c|c|}
\hline Descriptive Statistics for: & \multicolumn{2}{l|}{} \\
\hline Current Tax Rate \& Effective Tax Rate & 35.000 & 38.933 \\
\hline Mean & 35.000 & 20.600 \\
\hline Median & 0.000 & 33.600 \\
\hline Std Error & 0.000 & 47.518 \\
\hline Std Dev & & \\
\hline
\end{tabular}

Source: Compiled by Author. 
Table 20. Linear Descriptive Statistics - Mann-Whitney 1 tailed Test Results for Whirlpool Inc.

\begin{tabular}{|c|c|c|c|c|}
\hline \multicolumn{2}{|c|}{ Mann-Whitney Test Results for: } & Whirlpool Inc & & \\
\hline \multicolumn{5}{|c|}{ Current Tax Rate } \\
\hline \multicolumn{5}{|c|}{ Effective Tax Rate } \\
\hline \multicolumn{5}{|c|}{ Descriptive Statistics } \\
\hline & Value & & Rank & \\
\hline & Current Tax Rate & Effective Tax Rate & Current Tax Rate & Effective Tax Rate \\
\hline 2009 year & 35.000 & 20.600 & 4.0 & 2.0 \\
\hline 2008 year & 35.000 & 81.700 & 4.0 & 6.0 \\
\hline 2007 year & 35.000 & 14.500 & 4.0 & 1.0 \\
\hline Median & 35.000 & 20.600 & 4.0 & 2.0 \\
\hline Sum & 105.000 & 116.800 & 12.0 & 9.0 \\
\hline $\mathrm{N}$ & 3 & 3 & 3 & 3 \\
\hline \multicolumn{5}{|c|}{ 1-tailed Test (Current Tax Rate $>$ Effective Tax Rate) } \\
\hline $\mathrm{U}$ & DF 1 & DF 2 & $\mathrm{P}$ & \\
\hline 6.000 & 3 & 3 & 0.350 & \\
\hline
\end{tabular}

Source: Compiled by Author.

Table 21. Linear Descriptive Statistics - Mann-Whitney 1 tailed Test Results for Whirlpool Inc.

\begin{tabular}{|c|c|c|c|c|}
\hline \multicolumn{2}{|c|}{ Mann-Whitney Test Results for: } & Whirlpool Inc & & \\
\hline \multicolumn{5}{|c|}{ Current Tax Rate } \\
\hline \multicolumn{5}{|c|}{ Effective Tax Rate } \\
\hline \multicolumn{5}{|c|}{ Descriptive Statistics } \\
\hline & Value & & Rank & \\
\hline & Current Tax Rate & Effective Tax Rate & Current Tax Rate & Effective Tax Rate \\
\hline 2009 year & 35.000 & 20.600 & 4.0 & 2.0 \\
\hline 2008 year & 35.000 & 81.700 & 4.0 & 6.0 \\
\hline 2007 year & 35.000 & 14.500 & 4.0 & 1.0 \\
\hline Median & 35.000 & 20.600 & 4.0 & 2.0 \\
\hline Sum & 105.000 & 116.800 & 12.0 & 9.0 \\
\hline $\mathrm{N}$ & 3 & 3 & 3 & 3 \\
\hline \multicolumn{5}{|c|}{ 1-tailed Test (Current Tax Rate $<$ Effective Tax Rate) } \\
\hline $\mathrm{U}$ & DF 1 & DF 2 & $\mathrm{P}$ & \\
\hline 3.000 & 3 & 3 & 0.800 & \\
\hline
\end{tabular}

Source: Compiled by Author.

Table 22. Descriptive Statistics - Mann-Whitney Tailed Test Results for Eaton Corp.

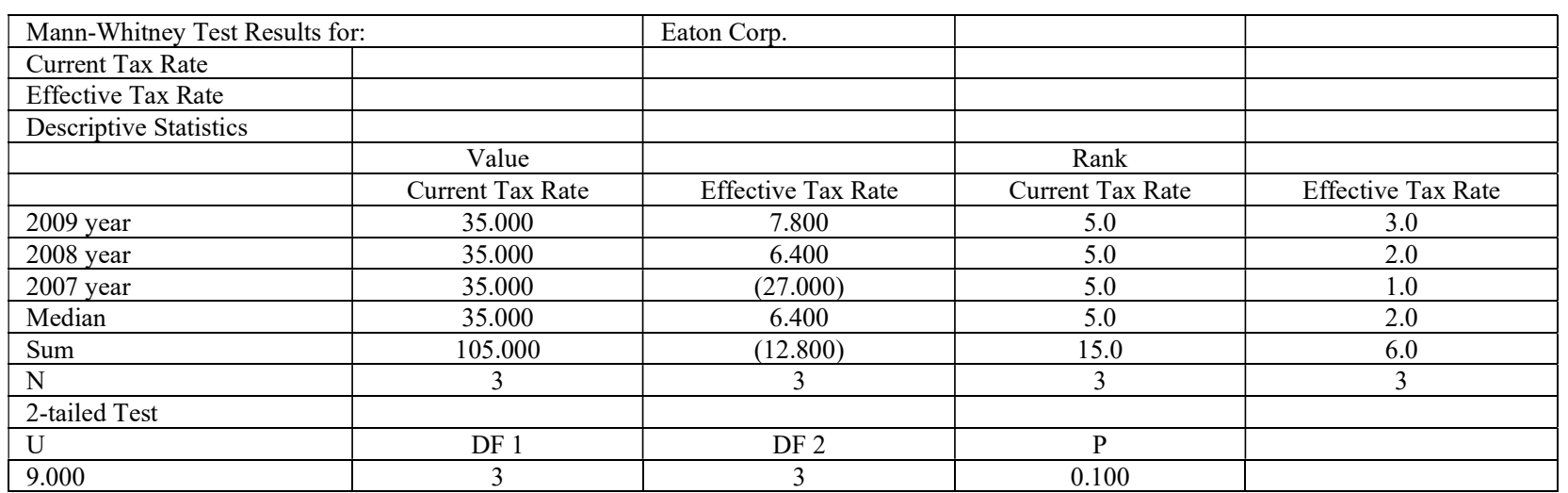

Source: Compiled by Author.

Table 23. Linear Descriptive Statistics - Mann-Whitney 2 tailed Test Results for Eaton Corp.

\begin{tabular}{|l|c|c|}
\hline \multicolumn{2}{|l|}{ Descriptive Statistics for: } & \multicolumn{2}{|c|}{} \\
\hline Current Tax Rate \& Effective Tax Rate & Current Tax Rate & $(4.267)$ \\
\hline Mean & 35.000 & 6.400 \\
\hline Median & 35.000 & 16.700 \\
\hline Std Error & 0.000 & 23.617 \\
\hline Std Dev. & 0.000 & \\
\hline
\end{tabular}

Source: Compiled by Author. 
Table 24. Linear Descriptive Statistics - Mann-Whitney 1 tailed Test Results for Eaton Corp.

\begin{tabular}{|c|c|c|c|c|}
\hline \multicolumn{3}{|c|}{ Mann-Whitney Test Results for: } & \multirow[t]{2}{*}{ Eaton Corp. } & \\
\hline \multicolumn{4}{|c|}{ Current Tax Rate } & \\
\hline \multicolumn{5}{|c|}{ Effective Tax Rate } \\
\hline \multicolumn{5}{|c|}{ Descriptive Statistics } \\
\hline & Value & & Rank & \\
\hline & Current Tax Rate & Effective Tax Rate & Current Tax Rate & Effective Tax Rate \\
\hline 2009 year & 35.000 & 7.800 & 5.0 & 3.0 \\
\hline 2008 year & 35.000 & 6.400 & 5.0 & 2.0 \\
\hline 2007 year & 35.000 & $(27.000)$ & 5.0 & 1.0 \\
\hline Median & 35.000 & 6.400 & 5.0 & 2.0 \\
\hline Sum & 105.000 & $(12.800)$ & 15.0 & 6.0 \\
\hline $\mathrm{N}$ & 3 & 3 & 3 & 3 \\
\hline \multicolumn{5}{|c|}{ 1-tailed Test (Current Tax Rate > Effective Tax Rate) } \\
\hline $\mathrm{U}$ & DF 1 & DF 2 & $\mathrm{P}$ & \\
\hline 9.000 & 3 & 3 & 0.049 & \\
\hline
\end{tabular}

Source: Compiled by Author.

Table 25. Linear Descriptive Statistics - Mann-Whitney 1 tailed Test Results for Eaton Corp

\begin{tabular}{|c|c|c|c|c|}
\hline \multicolumn{2}{|c|}{ Mann-Whitney Test Results for: } & Eaton Corp. & & \\
\hline \multicolumn{5}{|c|}{\begin{tabular}{l|l} 
Current Tax Rate & \\
\end{tabular}} \\
\hline \multicolumn{5}{|c|}{ Effective Tax Rate } \\
\hline \multicolumn{5}{|c|}{ Descriptive Statistics } \\
\hline & Value & & Rank & \\
\hline & Current Tax Rate & Effective Tax Rate & Current Tax Rate & Effective Tax Rate \\
\hline 2009 year & 35.000 & 7.80 & 5.0 & 3.0 \\
\hline 2008 year & 35.000 & 6.40 & 5.0 & 2.0 \\
\hline 2007 year & 35.000 & $(27.00)$ & 5.0 & 1.0 \\
\hline Median & 35.000 & 6.40 & 5.0 & 2.0 \\
\hline Sum & 105.000 & $(12.80)$ & 15.0 & 6.0 \\
\hline $\mathrm{N}$ & 3 & 3.00 & 3 & 3 \\
\hline \multicolumn{5}{|c|}{ 1-tailed Test (Current Tax Rate $<$ Effective Tax Rate) } \\
\hline $\mathrm{U}$ & DF 1 & DF 2 & $\mathrm{P}$ & \\
\hline 0.000 & 3 & 3 & 1.000 & \\
\hline
\end{tabular}

Source: Compiled by Author.

If the null hypothesis had been that the median for Set 1 (Current Tax Rate) was less than the median for Set 2 (Effective Tax Rate), then the one-tailed $U$ test would have had a $U$ value of 3.000 (degrees of freedom of 3 and 3) with probability (P) of 0.800 , and we would reject the null hypothesis that Set 1 (Current Tax Rate) decreased compare to the Set 2 (Effective Tax Rate). F-Test for the Significance of the Difference between the Variances of the Two Independent Samples. P > .05 indicates no significant difference detected between the variances of the two samples $t$ test assuming unequal sample variances and applicable only to independent samples. I obtained the $t$ value by dividing the Mean difference $(35.000-(-4.267)=39.267)$ by the standard error (-16.700) which is equal to -2.3513 for 2-tailed test. The test result of the one-tailed $U$ test are given, including the $U$ value $(9.000)$, degree of freedom $(D F 1=3$, and $D F 2=3)$ and the probability value $(P)$, which in this example is $<0.05$ and indicates that we accept the hypothesis that the median for Set 1 (Current Tax Rate) is greater than the median for Set 2 (Effective Tax Rate). If the null hypothesis had been that the median for Set 1(Current Tax Rate) was less than the median for Set 2 (Effective Tax Rate), then the one-tailed U test would have had a $U$ value of 0.0 (degrees of freedom of 3 and 3 ) with probability $(\mathrm{P})$ of 1.000 , and we would reject the null hypothesis that Set 1 (Current Tax Rate) decreased compare to the Set 2 (Effective Tax Rate).

In this study, a $t$ test is performed to test whether there are any significant differences on Current Tax Rate (CTR) and Effective Tax Rate (ETR) ratios between the firms with foreign ownership participation in capital structure and domestic subsidiaries.

The empirical findings obtained from $t$-test are summarized as follow: Whirlpool data yielded a $T$ statistic of 0.11 and $P$ value of 0.1 while Eaton returned a T statistic of -2.35 and a $P$ value of 0.049 .

The hypotheses to test the effect of Current Tax Rate on Effective Tax Rate are:

$\mathrm{H}_{0}$ : There is no significant difference between Current Tax Rate (CTR) and

Effective Tax Rate (ETR),

$\mathrm{H}_{1}$ : There is significant difference between Current Tax Rate (CTR) and 


\section{Effective Tax Rate (ETR).}

Model-3 T-test reveals that, for year $2007-2009, H_{0}$ is rejected $(\mathrm{p}=0.100<0.05)$. When CTRs \& ETRs are compared, it is found that the company Eaton Inc. is different significantly after t-test was performed $\left(\mathrm{t}_{0} .0_{5} ; 3\right.$ $=-2.35)$. According to the finding, ETR of Eaton is higher than ETRs of Whirlpool, which is $43.2 \%$.

In the study, an analysis of performance of current tax rate and effective tax rate conducted to addresses the impact of transfer pricing accounting treatment on effective tax rate was undertaken. Whether there is any significant performance difference between the CTR and ETR for both listed companies were reviewed.

In the paper, $t$-test statistics confirms the hypothesis that Whirlpool Inc. in respect to ETRs have performed better than Eaton Corp. Therefore, the results show that Whirlpool Inc. with foreign ownership performs better than Eaton Corp. with foreign ownership for the period 2007-2009. The statistical measurement shows that Whirlpool did not use the appropriate level of the charging the transfer pricing because the total tax liabilities increased in 2008 instead of a decrease. This indicates that the company charged the foreign subsidiary transfer pricing amount that was too low.

\section{Conclusions}

The U.S. balance of payment summarizes all the economic transactions between the tax home country and the rest of the world. These transactions include goods, services, transfer payments, loans, and investments. Inflation and interest rates, national income growth, and changes in money supply have a significant impact on the U.S. currency and future exchange rates. All these factors may affect the balance of payments. The balance of payments shows the net effect of all currency global transaction of a country over a given period. When the balance of payments of a country decline over a given period of several years then it is an indication of weakening of the value of the dollar as a national currency. It will be a threat to the currency's stability. National income, money supply, employment and foreign exchange rates are among the most important variables that are affected by a deficit or surplus. Whirlpool and Eaton should be aware that when the foreign country's balance of payments shows deficits year after year, the foreign government will eventually turn to different tools to reduce its deficit. Therefore, Whirlpool and Eaton should be alert for possible restrictive fiscal policies, such as currency for the purpose of controlling inflation. Whirlpool and Eaton may change their global transfer pricing policies to alleviate the impact of the new national policies of the United States on cash movements, the value of goods or services transferred into or out of the country, and the foreign exchange risk (Cole, R.T., 2006).

This research study should motivate foreign subsidiary managers to achieve the highest possible profits of subsidiaries in harmony with the global overall objectives. Also, the findings may minimize the international transaction cost for United States multinational companies by minimizing tariffs, income tax, liabilities in both home and host countries, foreign exchange risk and conflicts with foreign governments' policies.

\section{References}

1. Adams, L. \& Drtina, R. (2008). Transfer Pricing for Aligning Divisional and Corporate Decisions, Business Horizons, 51, 411-417. http://dx.doi.org/10.1016/j.bushor.2008.03.008

2. Adams, C., \& Coombes, R. (2003). Global transfer pricing principles and practice. London: LexisNexis UK. Available at: https://www.bloomsburyprofessionalonline.com/applib/newsitem/2488/global-transferpricing-principles-and-practice

3. Alm, J., Martinez-Vazquez, J., \& Rider, M. (2006). The challenges of tax reform in a global economy. New York: Springer. Available at: https://www.springer.com/gp/book/9780387299129

4. Avi-Yonah, R. S. (2007). International tax as international law an analysis of the international tax regime. New York: Cambridge University Press. https://repository.law.umich.edu/cgi/ viewcontent.cgi?article= $1006 \&$ context $=$ law econ archive

5. Baker, J.C. \& McKenzie, G.W. (1993). Intercompany pricing guide to the new 1993 United States rules. The Hague: Kluwer Law and Taxation Publishers.

6. Baldenius, T., Melumad, N. \& Reichelstein S. (2004). Integrating Managerial and Tax Objectives in Transfer Pricing, The Accounting Review, 79 (3), 591- 615. http://dx.doi.org/10.2308/accr.2004.79.3.591

7. Bergstrand, J. (2012). Management accounting a cases approach. Upper Saddle, NJ: Pearson. Available at: https://www.pearson.ch/HigherEducation/Pearson/EAN/9780273757054/Management-Accounting-ACases-Approach 
8. Boos, M. (2003). International transfer pricing the valuation of intangible assets. The Hague: Kluwer Law International. Available at: https://lib.ugent.be/catalog/rug01:000788154

9. Buckley, P. J. (2004). The challenge of international business. New York: Palgrave Macmillan.

10. Cadwalader, W.T. (1992). Section 482 program March 5, 1992. New York: Cadwalader, Wickersham \& Taft.

11. Case, K.E., Fair, R.C. and Oster, S.M. (2009). Principles of microeconomics. ( $9^{\text {th }}$ ed.). Upper Saddle, NJ: Prentice Hall. Available at: https://trove.nla.gov.au/work/7146893

12. Chan, K. \& Hung - Chow, L. (1997). An Empirical Study of Tax Audits in China on International Transfer Pricing", Journal of Accounting \& Economics, 23, 83-112. http://dx.doi.org/10.1016/S01654101(96)00445-4

13. Cole, R. T. (2006). Practical guide to U.S. transfer pricing (3rd ed.). Newark, NJ: LexisNexis.

14. Economic Partners (2017). Tranfer Pricing Eaton. Retrieved from https://www.econpartners.com/ 2017/08/21/eaton-v-commissioner/

15. Elliott, J. \& Emmanuel, C. (2000). International Transfer Pricing: Searching for Patterns, European Management Journal, 18(2), 216-222. http://dx.doi.org/10.1016/S0263-2373(99)00093-6

16. Gox, R. F., \& Schiller, U. (2007). An economic perspective on transfer pricing. Handbook of management accounting research. 673-695, 2. Oxford, UK: Elsevier Ltd. 673-695

17. Nguyen Tan, P.(2009). Transfer pricing the Vietnamese system in the light of the OECD guidelines and the systems in certain developed and developing countries. (Unpublished Doctoral Dissertation). Jonkoping International Business School, Jonkoping University.Jonkoping, Sweden. Available at: https://www.econbiz.de/Record/transfer-pricing-the-vietnamese-system-the-light-the-oecd-guidelinesand-the-systems-certain-developed-and-developing-countries-nguyen-phat-tan/10003906745

18. Samuelson, L. (1982). The multinational firm with arm's length transfer price limits. Journal of International Economics, 13(3-4), 365-374. http://dx.doi.org/10.1016/0022-1996(82)90064-2

19. Walden, G. (2003). EDGAR: The investor's guide to making better investments. New York McGraw-Hill.

20. Wong, H., Nassiripour, S., Mir, R. \& Healy, W. (2011). Transfer Price Setting in Multinational Corporations, International Journal of Business and Social Science, 2(9), 10-14. Available at: http://www.revistaespacios.com/a20v41n05/20410521.html 